University of Wollongong

Research Online

Faculty of Business - Papers (Archive)

Faculty of Business and Law

2014

Analysing banks' intermediation and operational performance using the Hicks-Moorsteen TFP index: The case of Iran

Amir Arjomandi

University of Wollongong, amira@uow.edu.au

Abbas Valadkhani

University of New England, abbas@uow.edu.au

Martin O'Brien

University of Wollongong, martinob@uow.edu.au

Follow this and additional works at: https://ro.uow.edu.au/buspapers

Part of the Business Commons

Research Online is the open access institutional repository for the University of Wollongong. For further information contact the UOW Library: research-pubs@uow.edu.au 


\title{
Analysing banks' intermediation and operational performance using the Hicks- Moorsteen TFP index: The case of Iran
}

\author{
Abstract \\ In order to analyse the impact of policy reforms on the performance of the banking sector in Iran we \\ present a decomposition of the Hicks-Moorsteen Total Factor Productivity (TFP). This entails a \\ comparison of both the intermediate and operating performances of different types of banks in the pre- \\ and post-reform eras. Our results show that under the intermediation approach, state-owned banks \\ (public banks) were considerably more efficient than private banks in the post-regulation period. In \\ contrast, under the operating approach, private banks were fully technically efficient and mix efficient in \\ both pre and post-reform eras. This paper highlights the importance of analysing performance from \\ multiple perspectives. The findings reflect public banks' mission to maximise loans to target groups while \\ private banks are motivated more by financial profit.

\section{Keywords} \\ moorsteen, tfp, index, analysing, case, banks, iran, intermediation, operational, performance, hicks

\section{Disciplines \\ Business}

\section{Publication Details} \\ Arjomandi, A., Valadkhani, A. \& O'Brien, M. (2014). Analysing banks' intermediation and operational \\ performance using the Hicks-Moorsteen TFP index: The case of Iran. Research in International Business \\ and Finance, 40 (2014), 111-125.
}




\title{
Analysing banks' intermediation and operational performance using the Hicks-Moorsteen TFP index: the case of Iran
}

\begin{abstract}
In order to analyse the impact of policy reforms on the performance of the banking sector in Iran we present a decomposition of the Hicks-Moorsteen Total Factor Productivity (TFP). This entails a comparison of both the intermediate and operating performances of different types of banks in the pre- and post-reform eras. Our results show that under the intermediation approach, state-owned banks (public banks) were considerably more efficient than private banks in the post-regulation period. In contrast, under the operating approach, private banks were fully technically efficient and mix efficient in both pre and post-reform eras. This paper highlights the importance of analysing performance from multiple perspectives. The findings reflect public banks' mission to maximise loans to target groups while private banks are motivated more by financial profit.
\end{abstract}

\section{Introduction}

In order to obtain a comprehensive assessment of the performance of any banking system, it is crucial to examine the productivity of individual banks considering both the intermediation and operating approaches. The former examines banks' loan making ability while the latter focuses on income and revenue generation. However, all previous studies of efficiency and productivity changes in the Iranian banking sector have analysed the results of the intermediation approach only (Hadian and Hosseini, 2004; Hakimabady et al., 2006; Hasanzadeh, 2007; Dadgar and Nemat, 2007; Arjomandi et al. 2012). The intermediation approach analyses how efficiently banks transform deposits from savers into loans of varying maturities for borrowers. Given the importance of the this role, previous studies have considered the value of loans as a measurable 
output and the magnitude of deposits along with labour and capital as three major inputs. Using a similar classification of input and output variables Arjomandi et al. (2012) found that the banking industry's technical efficiency deteriorated considerably soon after the regulatory changes in 2005, and the overall productivity performance also exhibited a similar outcome over the period 2007-2008. Arjomandi et al. (2012, p.295) stated that the overall reduction of efficiency "was mainly attributable to the performance of private banks which became technically inefficient (the worst bank-group) and more scale and mix inefficient over this period, particularly in 2008”. Arjomandi et al. (2012, p.295) have also argued that "lower technical efficiency of private banks over this period can be attributed to their poor management of increasing deposits”.

However, merely focusing on the intermediation services and excluding the revenue side of the banking system is likely to provide an incomplete picture of productivity changes. This is particularly relevant when we compare public banks to private banks. It is important to note that the private banks' major goal is to maximise income and profits, whereas the public banks in countries like Iran have to follow the government's regulations and provide services to specific groups. Thus, it is of paramount importance to compare and contrast the performance of the Iranian private and public banks using the results of productivity and efficiency changes from both the intermediating and operating views. On this same issue, Berger and Mester (2003, p.80) state that the use of the profit-oriented (operating) approach "may help take into account unmeasured changes in the quality of banking services by including higher revenues paid for the improved quality, and may help capture the profit maximisation goal by including both the costs and revenues”. The operating approach defines banks’ output as total revenue (interest and noninterest income) and considers interest and non-interest expenses as inputs.

The major contributions of this study are thus two-fold. First, by comparing and contrasting the results of the intermediation approach (Arjomandi et al., 2012) with the new results obtained 
from the operating approach, we will be able to provide a better assessment of both private and public banks in Iran pursuing different goals. Second, this study is the first attempt to use the Hicks-Moorsteen TFP index to compare the above two approaches in one study. Almost all previous studies have chosen to compare these approaches using the Malmquist TFP index. However, in Section 3 we show that the constant returns to scale assumption needed for the Malmquist index may be unrealistic when applied to the banking sector and that the use of the more flexible Hicks-Moorsteen index is more appropriate.

The remainder of this paper is structured as follows: Section 2 provides a short introduction to the Iranian banking industry. Section 3 includes an explanation on why we have adopted the Hicks-Moorsteen TFP index instead of the popular Malmquist TFP index. It also presents a literature review of the previous studies that have considered research on productivity growth and the efficiency of Iranian banks. Section 4 concisely discusses the methodology used in the study. Section 5 explores the data utilized in the paper. Section 6 discusses our empirical results, followed by some concluding remarks in Section 7.

\section{The Iranian banking industry}

Until 1979, Iran’s banking system was dominated by Western banking norms and practices. However, following the Islamic Revolution in 1979, all foreign bank representative offices were closed. Consistent with Islamic banking practices, an interest-rate free banking law was ratified by Iran's parliament in 1983, which banned the charging of interest on all lending and borrowing activities. As the abolition of interest on bank deposits would make saving and term deposits unattractive, the Central Bank of Iran (CBI) also established an alternative system whereby depositors would receive a return depending on a bank's investment profitability at the end of a financial year. Instead of interest rates, the CBI introduced minimum investment returns (also 
referred to as "profit rates") that were applicable to term and saving deposits of varying maturities (Valadkhani, 2004).

An important development in the post-Islamic revolution period was the reintroduction of private banks in 2001. Since then, they have played an increasingly important role in the Iranian financial system. As reported by the CBI (2008), the ratio of private banks' deposits to total deposits in the banking system increased from 0.7 percent in 2001 to 23.8 percent in 2008, with the ratio of private banks' claims on the private sector increasing from 0.5 percent in 2000 to 19.9 percent in 2008.

The banking industry has undergone substantial changes over the last decade caused by increased government regulation and technological advances, resulting in extensive restructuring. The Iranian government regulatory initiatives launched in 2005 can be regarded as the most influential change during this period, requiring all banks to reduce deposit and loan profit rates considerably. In addition, the government imposed preferential profit rates and conditions. For example, they required public banks to assign higher priority in their lending operations to areas such as low cost housing and small and medium enterprises (CBI, 2007a). Consequently, public banks increased their loan portfolios to by 30 percent and 29 percent in 2006 and 2007, respectively. ${ }^{1}$ However, the ratio of public banks’ non-performing loans (NPLs) to their total loans almost doubled immediately, from approximately 5 percent in 2005, to 10.4 and 9.7 percent in 2006 and 2007, respectively (CBI 2005; 2007b). As a result, one may argue that these changes in the profit rates and NPLs have negatively affected the banks' management success in controlling costs and generating revenues. Therefore, with such a significant regulatory upheaval in the banking industry, a study of Iranian banks’ operating performance in both pre and post-reform is particularly pertinent and timely.

\footnotetext{
${ }^{1}$ According to CBI (2008), in 2005, 90 percent of the total loans and advances were allocated to the private sector and the rest were allocated to the public sector. This proportion increased to 93 and 94 percent in 2006 and 2007 , respectively.
} 


\section{Literature review}

\subsection{Why the Hicks-Moorsteen TFP index}

To date the Malmquist index has been used as a dominant methodology to examine TFP growth within a multiple inputs and outputs framework. This approach has been applied in numerous industries and sectors such as agriculture, postal sector, airports, steel industry, as well as the financial and banking sector (see , inter alia, Mukherjee et al. 2001; Ma et al., 2002; Sturm and Williams 2004; Coelli and Rao 2005; Iturralde and Quirós, 2008; Babalos et al., 2012; Gitto and Mancuso, 2012). With respect to the empirical literature specifically relating to banks, Fethi and Pasiouras (2010) demonstrate that almost all of the 196 studies analysing banking performance via the estimation of TFP growth employed a DEA-type Malmquist index, see for example Berg et al. (1992), Grifell-Tatje and Lovell (1997), Gilbert and Wilson (1998), Wheelock and Wilson (1999), Worthington (1999), Mukherjee et al. (2001), Sathye (2002), Casu and Girardone (2004), Casu et al. (2004), Sturm and Williams (2004), Sufian (2006), Chen and Lin (2007), Sufian (2008), and Figueira et al. (2009).

The Malmquist productivity index was initially introduced by Caves et al. (1982) as a theoretical index. Färe et al. (1992) later merged Farrell’s (1957) measurement of efficiency with the measurement of productivity developed by Caves et al. (1982) to develop a new Malmquist index of productivity changes. Färe et al. (1992) demonstrated that the resulting TFP indexes could be decomposed into technical and efficiency change components. Färe et al. (1994) subsequently decomposed the efficiency change further into pure technical efficiency change and change in scale efficiency, a development which ultimately resulted in the Malmquist index becoming the most widely popular empirical index of productivity changes. However, the constant returns to scale (CRS) technology assumption required for its estimation has received mixed responses in the literature. For example, Grifell-Tatje and Lovell (1995) and Coelli and Rao (2005) are in favour of the CRS assumption and argue that the adoption of non-constant 
returns to scale in the Malmquist productivity index may lead to the inaccurate measurement of TFP gains or losses arising from scale economies. On the other hand, other studies such as Ray and Desli (1997) and Wheelock and Wilson (1999) argue that the decomposition of the CRS Malmquist index undertaken by Färe et al. (1994) may not be reliable. For instance, Wheelock and Wilson (1999) show that when a firm's location in the production possibility set has not changed (from one period to the next), and the change to scale efficiency is purely the result of a shift in the VRS estimate of technology, employing a CRS assumption would result in a zero technical change estimate. Under these circumstances they argue that the CRS estimate of technology is statistically inconsistent. In addition to these general concerns on the CRS assumption, many studies have found that such an assumption is not an appropriate choice for analysing banks’ performance as they usually face factors such as imperfect competition and government regulations (see McAllister and McManus 1993; Mitchell and Onvural 1996; Clark 1996; Wheelock and Wilson 1997; Wheelock and Wilson 1999).

O’Donnell (2012a) casts further doubt on the Malmquist productivity index as a TFP index and demonstrated that that the popular Malmquist TFP index of Caves et al. (1982) cannot be used to reliably measure TFP changes except in special cases. O'Donnell's argument is in line with the finding of a study by Kerstens et al. (2010) demonstrating that the Malmquist index is not always a TFP index. Kerstens et al. (2010) and Epure et al. (2011) point out that the distance functions constituting the Malmquist TFP index may well be undefined when estimated by general technologies ${ }^{2}$. In contrast, Kerstens et al. (2010), Epure et al. (2011) and O’Donnell (2012a) state that the lesser known Hicks-Moorsteen productivity index is well-defined under weak conditions on technology (weak assumptions of strong disposability and VRS) and thus more reliable than the Malmquist TFP index. For these reasons, following Epure et al. (2011) and Arjomandi et al. (2012), this study employs the Hicks-Moorsteen TFP index to analyse

\footnotetext{
${ }^{2}$ For more details on the issue of infeasibility of the distance functions, see Bjurek (1996), Chung et al (1997), Epure et al. (2011), and Kenjegalieva and Simper (2011).
} 
banks’ performance without making any assumption concerning firm-optimizing behaviour, the structure of markets, or returns to scale. ${ }^{3}$

\subsection{Literature review of Hicks-Moorsteen studies on banking productivity}

As a result of the above shortcomings prevalent in the Malmquist index there has been an increasing interest in using Hicks-Moorsteen indices to measuring firms' productivity in different areas in recent years. Some important applications of this index include O’Donnell (2010a; 2012a; 2012b) and Hoang (2011) in the agricultural sector, Simões and Marques (2012) in the waste sector and Epure et al. (2011), Arjomandi et al. (2012), and Arora and Arora (2012; 2013) in the context of the banking sector.

Epure et al. (2011) examined the productivity growth of 73 private and savings banks operating in Spain during the period 1998-2006. The authors followed the intermediation approach and found that savings banks that expanded outside their original markets achieved greater productivity gains. They also found a consistent TFP growth of the Spanish banking industry originated at the end of the deregulation of the banking sector. Again using the intermediation approach, Arora and Arora (2012) investigated the productivity growth of the Indian public banks during the post-liberalisation period 1991-2009. They found a significant difference in the productivity growth experienced by the State Bank of India Group and the Nationalised Banks with the latter showing higher TFP growth. They argued that the difference between the two groups of banks was due to greater technological progress experienced in the Nationalised Banks. In another study of the Indian banks, Arora and Arora (2013) used the same approach to examine TFP changes of the whole industry in the period 1991-2008. Their findings indicate that the TFP of the banking industry has not progressed significantly in this period mainly because of the overall technological regress.

\footnotetext{
${ }^{3}$ It should be noted that, similar to the Malmquist productivity index, the Hicks-Moorsteen index can be computed without price data.
} 
So far in the literature, there has been little research work on the performance of the Iranian banking industry. Hadian and Hosseini (2004) investigated the intermediation activities of 10 Iranian public banks (6 commercial and 4 specialised banks) during the period 1997-1999, and found that the specialised banks were considerably more technically efficient than the commercial banks. Hasanzadeh (2007) also used the same standard intermediation model as that of Hadian and Hosseini (2004) to examine the technical efficiency of all the public and private banks in the period 1997-2003. The results of his study were consistent with those of Hadian and Hosseini (2004). Hasanzadeh (2007) also found that the private banks were more technical efficient than the public banks, and pointed out that the government ownership had a substantial negative effect on the public banks' control of inputs and outputs. As discussed earlier, Arjomandi et al. (2012) have undertaken the most recent study of the banks' efficiency and productivity in Iran for the pre and post-regulation period 2003-2008. They categorise the authorised deposit taking institutions into three main groups: commercial banks, specialised banks and private banks. Their results indicate that the industry's overall technical efficiency rose during the pre-regulation period and dropped just after the implementation of regulatory changes in 2006. They showed that, overall, public banks were more technically efficient than private banks under the intermediation approach. However, Arjomandi et al. (2012), found that in general private banks were more scale and mix efficient than their public counterparts, particularly the specialised banks. They stated that as a result of the technological changes and government regulations, the overall TFP growth became positive during 2004-2007 but extensively negative in 2007-2008.

Overall, in all previous studies, the profit-maximising role of the Iranian banks has been ignored. To fill this important gap in the literature, our study employs the Hicks-Moorsteen TFP index to analyse both intermediation and operational performance of the banks during the pre 
and post-reform eras. In addition, this study provides various components of efficiency changes for each individual bank, which can be insightful for bank managers as well as policy makers.

\section{Methodology}

\subsection{The Hicks-Moorsteen TFP index}

The following standard definition of TFP is used in this paper: $T F P_{n t}=Y_{n t} / X_{n t}$ where $T F P_{n t}$ indicates the TFP of decision making unit (DMU) $n$ in the period $t, Y_{n t} \equiv Y\left(y_{n t}\right)$ is an aggregate output and $X_{n t} \equiv X\left(x_{n t}\right)$ denotes an aggregate input. This definition allows us to express index numbers that measure changes in TFP as the ratio of an output quantity index to an input quantity index. Such index numbers are referred to as multiplicatively-complete indexes. O’Donnell (2010a; 2012a) proved that the Hicks-Moorsteen TFP index is consistent with the above definition of TFP and, hence, a multiplicatively-complete index ${ }^{4}$. In addition, this index is the only multiplicatively-complete index that can be computed without requiring price data. The Hicks-Moorsteen TFP index is defined as:

$$
T F P_{H M}^{t, t+1}=\left(\frac{D_{o}^{t+1}\left(x^{t+1}, y^{t+1}\right) D_{o}^{t}\left(x^{t}, y^{t+1}\right)}{D_{o}^{t+1}\left(x^{t+1}, y^{t}\right) D_{o}^{t}\left(x^{t}, y^{t}\right)} \frac{D_{I}^{t+1}\left(x^{t}, y^{t+1}\right) D_{I}^{t}\left(x^{t}, y^{t}\right)}{D_{I}^{t+1}\left(x^{t+1}, y^{t+1}\right) D_{I}^{t}\left(x^{t+1}, y^{t}\right)}\right)^{1 / 2}
$$

where $D_{O}^{T}(x, y)=\min \left\{\delta>0:(x, y / \delta) \in P^{T}\right\}$ and $D_{I}^{T}(x, y)=\max \left\{\rho>0:(x / \rho, y) \in P^{T}\right\}$ are output and input distance functions, respectively, and $P^{T}$ denotes the period- $T$ production possibilities set in these functions. ${ }^{5}$ We adopt the nonparametric DEA method used by O’Donnell (2010a; 2012a; 2012b) and Hoang (2011) to compute these distance functions. DEA does not require any restrictive assumptions regarding the functional form and efficiency distribution. It must be noted, however,

\footnotetext{
${ }^{4}$ In general, any TFP index that can be expressed as aggregate outputs and inputs is said to be multiplicativelycomplete; where completeness is an essential requirement for an economically meaningful decomposition of the TFP change.

${ }^{5}$ This decomposition is referred to as the Hicks-Moorsteen TFP index because Diewert (1992) attributed its origins to Hicks (1961) and Moorsteen (1961).
} 
that DEA has its own limitations and makes no allowance for stochastic noise, and as such one should be cautious in interpreting the results. Due to this statistical shortcoming, any possible measurement errors in the data could make the estimated efficiency and TFP indexes to some extent biased. One possible solution for quantifying the magnitude of measurement errors and capturing the resulting statistical noise would be to estimate an econometric method such as stochastic frontier analysis. However, the use of such an approach is not possible in this paper as there are only 14 observations per year, one for each bank. Notwithstanding these possible shortcomings, we perceive that the potential risks associated with using O'Donnell's method are outweighed by the benefits and valuable insights that this advanced technique can provide us.

\subsection{The components of TFP change}

Fig. 1 shows mapping of multiple-input and multiple-output production points onto an aggregate quantity space. The curve passing through point $C$ denotes a mix-restricted frontier, representing the boundary set of all technically feasible aggregate input-output combinations which hold the same input and output mix as the DMU operating at point $A$. DMU $A$ can boost its TFP by expanding outputs and achieving point $C$. Thus, the vertical distance from point $A$ to point $C$ shows the measure of output-oriented technical efficiency (OTE), and can be defined as:

$$
\mathrm{OTE}_{t}=\frac{Y_{t}}{\bar{Y}_{t}}=\frac{\tan a}{\tan c}
$$

where $\bar{Y}_{t}$ is the maximum aggregate output which is technically feasible when using $x_{t}$ to generate a scalar multiple of $y_{t}$. Hence, TFP of the DMU, and the maximum TFP possible (holding the input vector and output mix fixed) are defined as $Y_{t} / X_{t}=\tan a$ and $\bar{Y}_{t} / X_{t}=\tan c$, respectively. 


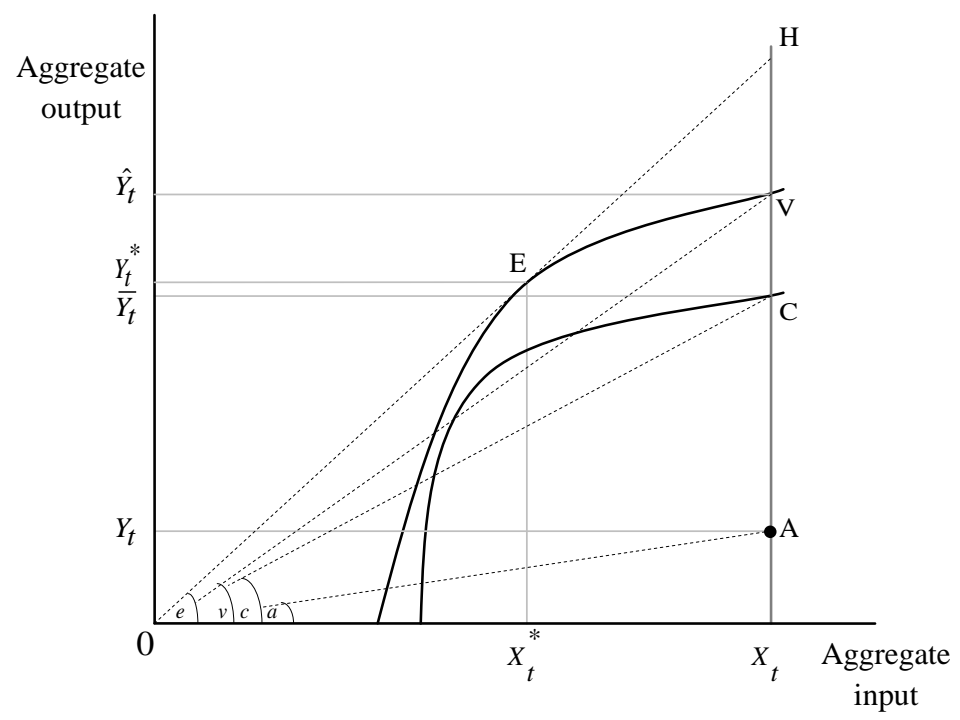

Fig. 1. Output-oriented decompositions of TFP efficiency (O’Donnell 2010a, p.535).

The curve passing through point $V$ is the unrestricted production frontier, which is the boundary of the production possibilities set when all mix restrictions are relaxed. Now the DMU can expand its aggregate output and move vertically from point $C$ to point $V$ in Fig. 1 . In view of this, the mix efficiency measure can be defined as the difference between the TFP at a technically efficient point on the mix-restricted frontier and the TFP at a point on the unrestricted frontier. Hence, the pure output-oriented mix efficiency (OME) is a measure of the change in productivity when restrictions on the input and output mix of the DMU are relaxed. It can be defined as:

$$
O M E_{t}=\frac{\bar{Y}_{t}}{\hat{Y}_{t}}=\frac{\bar{Y}_{t} / X_{t}}{\hat{Y}_{t} / X_{t}}=\frac{\tan c}{\tan v}
$$

where $\hat{Y}_{t}$ is the maximum aggregate output which is feasible when using $x_{t}$ to produce any given output vector.

Obviously, any increase in technical and mix efficiency implies a rise in the TFP. However, when one moves from point $A$ to point $V$ the DMU becomes technically efficient and mix efficient, but its TFP is not maximized. In other words, the DMU's TFP will be maximized only by moving to the point $E$, where a straight line through the origin is tangential to the unrestricted 
production possibilities frontier. Point $E$ is named as the point of optimum productivity. The difference between the TFP at points $V$ and $E$ is defined as the residual scale efficiency measure. In sum, residual scale efficiency is a measure of the difference between TFP at a technically and mix efficient point and TFP at the point of optimum productivity. The vertical distance from point $V$ to point $H$ then represents the measure of residual output-oriented scale efficiency (ROSE):

$$
\operatorname{ROSE}_{t}=\frac{\hat{Y}_{t} / X_{t}}{Y^{*}{ }_{t} / X^{*}}=\frac{\tan v}{\tan e}
$$

where $Y_{t}^{*}$ and $X_{t}^{*}$ are the aggregate output and input quantities at point $E$. Hence, $T F P_{t}^{*}$ is defined as the maximum TFP possible using any technically feasible inputs and outputs, and is depicted as $Y_{t}^{*} / X_{t}^{*}=\tan e$. According to the definitions provided above, we can write the following equation for TFP efficiency:

$$
\text { TFP efficiency }=T F P E_{t}=\frac{T F P_{t}}{T F P_{t}^{*}}=\frac{\tan a}{\tan e}=\frac{\tan a}{\tan c} \frac{\tan c}{\tan v} \frac{\tan v}{\tan e} .
$$

This measure of TFP efficiency measures the proportionate increase in TFP as the DMU moves all the way from point $A$ to point $E$. Fig. 1 shows that there are many pathways from $A$ to $E$. Thus there are several ways to decompose TFP efficiency in Equation (5). Pathway ACVE is used for TFPE $E_{t}$ here.

With regards to the efficiency measures defined above, the following output-oriented decomposition can be defined as:

$$
T F P E_{t}=\frac{T F P_{t}}{T F P_{t}^{*}}=\frac{\frac{Y_{t}}{X_{t}}}{\frac{Y_{t}^{*}}{X_{t}^{*}}}=O T E_{t} \times O M E_{t} \times R O S E_{t}
$$

which can be rewritten as: 


$$
T F P_{t}=T F P_{t}^{*} \times\left(O T E_{t} \times O M E_{t} \times R O S E_{t}\right)
$$

A similar equation can be formulated for any other DMU like $m$ in period $s$. Then, the index number which compares the TFP of DMU $n$ in period $t$ with the TFP of DMU $m$ in period $s$ is defined as:

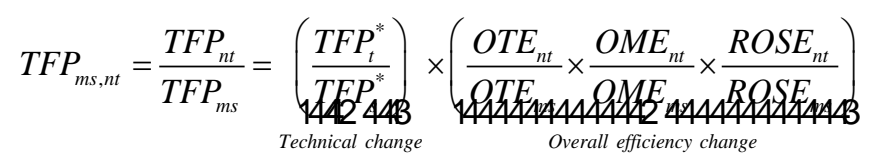

The first component in the brackets on the right-hand side of Equation (8) measures technical change from time period $s$ to $t$, quantifying the ratio of the maximum TFP possible, using the technology feasible in periods $t$ and $s$ respectively. Depending on whether $T F P_{t}^{*} / T F P_{s}^{*}$ is greater or less than 1, we can quantify the extent of technical improvement or technical decline, respectively. In Fig. $1 \mathrm{TFP}_{t}^{*} / \mathrm{TFP}_{s}^{*}$ measures the change in the slope of the line which passes through point $E$. The reminder of Equation (8) measures TFP efficiency change or overall efficiency change. This includes technical efficiency change, mix efficiency change and (residual) scale efficiency change. We have applied equation (8) in the current study to decompose and examine various components of the technical efficiency changes.

\section{Intermediation approach vs. operating approach}

The intermediation approach, first proposed by Sealey and Lindley (1977) focuses on various services as banks' output, with labor, capital, and various funding sources as inputs. This approach has been used in many studies such as Berger et al. (1987), Aly et al. (1990), Hancock (1991), Bauer et al. (1998), Wheelock and Wilson (1999), Burgess and Wilson (1995), Sathye (2001), Neal (2004), Sufian (2007), and Maghyereh and Awartani (2012). Following these studies, and consistent with Arjomandi et al. (2012), this paper employs three inputs to produce three outputs. The inputs are labor $\left(x_{1}\right)$, measured by the number of full-time equivalent 
employees on the payroll at the end of each period; physical capital $\left(x_{2}\right)$, measured by the book value of premises and fixed assets; and purchased-fund input $\left(x_{3}\right)$, which encompasses all time and savings deposits and other borrowed funds (excluding demand deposits). On the output side, production is represented by total demand deposits $\left(y_{1}\right)$; public sector loans $\left(y_{2}\right)$, including loans and advances for government-owned enterprises; and private (non-public) loans $\left(y_{3}\right)$, including conventional and Islamic loans for privately owned enterprises.

In comparison, the profit-oriented operating approach proposed by Drake et al. (2006) in the context of DEA, views banks as business-decision-making units with the final objective of generating maximum revenue from the total cost incurred from running the business. Accordingly, it defines banks' output as total revenue (lending and non-lending), and inputs consisting of costs such as borrowing and operating expenses (see e.g., Leightner and Lovell 1998; Avkiran 1999; Sturm and Williams 2004; Drake et al. 2006; Pasiouras 2008; Kenjegalieva and Simper 2011). In our operating approach, we employ three specific inputs (borrowing expenses $\left(x_{1}\right)$, employee expenses $\left(x_{2}\right)$ and other operating expenses $\left.\left(x_{3}\right)\right)$ and two specific outputs (lending income $\left(y_{1}\right)$ and non-lending income $\left(y_{2}\right)$ ).

All the data utilised in this paper were obtained from Iran’s Central Bank archives (CBI 2005; 2008). We considered all but three banks operating in the Iranian banking system, as these three were not homogeneous in terms of their input and output mixes. We used a balanced panel data covering 14 banks over a six-year period (2003-2008). As stated earlier this time period was selected to encompass both the pre and post-reform eras, and the coverage of our dataset is similar to that of Arjomandi et al. (2012). Due to the data availability and definitional problems, an expansion of this sample was not feasible. The full list of our 14 sample banks is shown in Table 1. Finally, all estimated indexes were obtained by using the DPIN software programme (O’Donnell, 2010b). 


\section{Empirical results}

As discussed earlier, Arjomandi et al. (2012) have examined the productivity and efficiency changes among the Iranian banks using the intermediation approach. However, the use of this approach may not necessarily capture the different goals pursued by private and public banks. Therefore, in this section we supplement the results of the intermediation approach (Arjomandi et al., 2012) with the results of operating approach to gain an in-depth understanding of productivity and efficiency changes from different angles. In addition, we provide various efficiency measures for individual banks to assist relevant decision makers in their assessment of the performance of private and public banking practices. Pure technical efficiency (OTE), scale efficiency (OSE) and mix efficiency (OME) for individual banks are presented using both the intermediation and operating approaches for commercial, specialised and private banks in three selected years (2004, 2006, and 2008) in Table $1 .^{6}$ The interpretation is as follows. A technical efficiency estimate equal to one indicates that the corresponding bank is located on the boundary of the production set, and thus is (relatively) efficient. An estimate below unity means that the bank is located under the frontier and hence it is technically inefficient. A DMU that has technical efficiency equal to 1 but displays scale and mix efficiency less than 1 is still on the frontier, but at a relatively unproductive point.

Table 1 shows that some of banks have been fully technically efficient, mix efficient as well as scale efficient under both approaches in certain years, e.g. National Bank, Bank Refah and Bank Eghtesad Novin in 2004, Bank Refah, Parsian Bank and Saman Bank in 2006, and, Parsian Bank and Bank of Industry and Mines in 2008. However, no individual bank (or category of bank) consistently stood out as the best performer using both approaches and estimates of efficiency.

\footnotetext{
${ }^{6}$ Results for the entire period on a yearly basis are available from the authors upon request.
} 


\section{Table 1}

Measures of output-oriented efficiency levels for individual banks (2004, 2006, and 2008)

\begin{tabular}{|c|c|c|c|c|c|c|c|c|c|}
\hline \multirow{3}{*}{ Financial institutions } & \multicolumn{9}{|c|}{ Intermediation approach } \\
\hline & \multicolumn{3}{|c|}{2004} & \multicolumn{3}{|c|}{2006} & \multicolumn{3}{|c|}{2008} \\
\hline & OTE & OSE & $\mathrm{OME}$ & OTE & OSE & OME & OTE & OSE & OME \\
\hline \multicolumn{10}{|l|}{ Commercial banks (public) } \\
\hline National Bank & 1 & 1 & 1 & 1 & 0.9916 & 1 & 1 & 0.899 & 1 \\
\hline Bank Saderat & 1 & 1 & 1 & 0.9569 & 0.8481 & 0.9185 & 0.7384 & 0.7901 & 0.9744 \\
\hline Bank Mellat & 1 & 0.9552 & 1 & 1 & 1 & 1 & 1 & 1 & 1 \\
\hline Bank Tejarat & 1 & 0.9446 & 0.9895 & 1 & 0.9524 & 0.9379 & 0.9615 & 0.9501 & 0.9021 \\
\hline Bank Sepah & 0.8924 & 0.9418 & 0.9483 & 1 & 0.8459 & 0.9337 & 0.9093 & 0.6442 & 0.9008 \\
\hline Bank Refah & 1 & 1 & 1 & 1 & 1 & 1 & 1 & 1 & 1 \\
\hline \multicolumn{10}{|l|}{ Specialised banks (public) } \\
\hline Agricultural Bank & 1 & 0.8808 & 1 & 1 & 0.9213 & 1 & 1 & 0.674 & 1 \\
\hline Housing Bank & 0.7052 & 0.7966 & 0.6313 & 0.9642 & 0.7443 & 0.6419 & 1 & 0.6932 & 0.612 \\
\hline Bank of Industry and Mines & 1 & 1 & 1 & 1 & 1 & 1 & 1 & 1 & 1 \\
\hline Export Development Bank & 1 & 1 & 1 & 1 & 0.6746 & 1 & 1 & 0.987 & 1 \\
\hline \multicolumn{10}{|l|}{ Private banks } \\
\hline Parsian Bank & 1 & 1 & 1 & 1 & 1 & 1 & 1 & 1 & 1 \\
\hline Bank Eghtesad Novin & 1 & 1 & 1 & 0.9588 & 0.9849 & 0.9322 & 1 & 0.9373 & 0.9059 \\
\hline Karafarin Bank & 0.7454 & 0.8995 & 0.8724 & 1 & 0.8258 & 1 & 1 & 0.6321 & 1 \\
\hline Saman Bank & 1 & 0.8538 & 1 & 1 & 1 & 1 & 0.5225 & 0.904 & 0.7429 \\
\hline \multirow{3}{*}{ Financial institutions } & \multicolumn{9}{|c|}{ Operating approach } \\
\hline & \multicolumn{3}{|c|}{2004} & \multicolumn{3}{|c|}{2006} & \multicolumn{3}{|c|}{2008} \\
\hline & OTE & OSE & $\mathrm{OME}$ & OTE & OSE & OME & OTE & OSE & OME \\
\hline \multicolumn{10}{|l|}{ Commercial banks (public) } \\
\hline National Bank & 1 & 1 & 1 & 1 & 1 & 1 & 1 & 1 & 1 \\
\hline Bank Saderat & 1 & 0.9382 & 0.7961 & 1 & 0.9957 & 0.9423 & 1 & 0.9459 & 0.9416 \\
\hline Bank Mellat & 1 & 0.9503 & 0.9759 & 1 & 0.9702 & 1 & 0.9691 & 0.9998 & 0.9898 \\
\hline Bank Tejarat & 1 & 1 & 0.8452 & 0.9397 & 0.9995 & 0.9841 & 0.9789 & 0.9993 & 0.9974 \\
\hline Bank Sepah & 1 & 0.9646 & 0.9552 & 1 & 1 & 1 & 1 & 1 & 1 \\
\hline Bank Refah & 1 & 1 & 1 & 1 & 1 & 1 & 0.9663 & 0.9437 & 0.9146 \\
\hline \multicolumn{10}{|l|}{ Specialised banks (public) } \\
\hline Agricultural Bank & 1 & 1 & 0.9976 & 1 & 1 & 1 & 1 & 1 & 1 \\
\hline Housing Bank & 1 & 0.9124 & 1 & 1 & 1 & 0.8855 & 0.8973 & 0.9969 & 0.9878 \\
\hline Bank of Industry and Mines & 0.7239 & 0.8671 & 0.6199 & 1 & 1 & 0.952 & 1 & 1 & 1 \\
\hline Export Development Bank & 1 & 0.8575 & 1 & 1 & 1 & 1 & 1 & 1 & 1 \\
\hline \multicolumn{10}{|l|}{ Private banks } \\
\hline Parsian Bank & 1 & 0.9447 & 1 & 1 & 1 & 1 & 1 & 1 & 1 \\
\hline Bank Eghtesad Novin & 1 & 1 & 1 & 0.9009 & 0.9795 & 0.9001 & 1 & 0.9859 & 1 \\
\hline Karafarin Bank & 1 & 1 & 1 & 1 & 0.889 & 1 & 1 & 0.809 & 1 \\
\hline Saman Bank & 1 & 0.928 & 1 & 1 & 1 & 1 & 1 & 1 & 1 \\
\hline
\end{tabular}

With regards to banks' output-oriented technical efficiency (OTE), the results vary between

the alternative approaches. For instance, in 2004 the Bank of Industry and Mines was fully 
efficient under the intermediation approach, but deemed inefficient under the operating approach $($ OTE $=0.72)$. Similar results were obtained for the Bank Tejarat in 2006, and Bank Mellat, Bank Refah and the Housing Bank in 2008. In other words, these public banks were more efficient in terms of providing output in the form of intermediation services (e.g. various loans) rather than maximizing their revenue. However, this was not the case for all public banks. Of note is that the Bank Saderat was fully technical efficient under the operating approach in all years, however, its efficiency declined over time under the intermediation approach. In general, commercial banks decreased their technical efficiency in 2008 under both approaches. In contrast, private banks largely maintained their technical efficiency levels, particularly in terms of maximising revenue under the operating approach.

In relation to banks' scale efficiency, Table 1 shows that scale inefficiency is a main source of all banks' overall inefficiency under the intermediation approach, in particular the public banks in the post-reform era (e.g. Bank Saderat, Bank Sepah and Housing Bank). This point will be analysed more thoroughly in the following tables.

With regards to the mix efficiency estimates, all of the private banks were fully mix and technically efficient under the operating approach in the selected years (with the only exception being Bank Eghtesad Novin in 2006). Not surprisingly, this finding suggests that almost all private banks enjoyed higher productivity in terms of achieving income-based objectives. However, this has not been achievable for public banks, as they are obliged to strictly follow the government's preferential credit policies in certain areas. For example, Table 1 shows that under the intermediation approach, the Housing Bank is the most mix inefficient in the three selected years, presumably because it is heavily influenced by government policies and priorities in terms of providing housing facilities to low-income groups. 
Table 2

Measures of output-oriented efficiency for bank categories (2003-2008)

\begin{tabular}{|c|c|c|c|c|c|c|c|}
\hline \multirow[b]{2}{*}{ Financial Institutions } & \multirow[b]{2}{*}{ Year } & \multicolumn{3}{|c|}{ Intermediation approach } & \multicolumn{3}{|c|}{ Operating approach } \\
\hline & & OTE & OSE & OME & OTE & OSE & OME \\
\hline \multirow[t]{6}{*}{ Commercial banks } & 2003 & 0.8905 & 0.9454 & 0.9379 & 0.9896 & 0.9794 & 0.9347 \\
\hline & 2004 & 0.9821 & 0.9736 & 0.9896 & 1.0000 & 0.9755 & 0.9287 \\
\hline & 2005 & 0.9820 & 0.9775 & 0.9804 & 0.9887 & 0.9852 & 0.9589 \\
\hline & 2006 & 0.9928 & 0.9397 & 0.9650 & 0.9900 & 0.9942 & 0.9877 \\
\hline & 2007 & 0.9950 & 0.6366 & 0.9532 & 0.9734 & 0.9873 & 0.9886 \\
\hline & 2008 & 0.9349 & 0.8806 & 0.9629 & 0.9857 & 0.9815 & 0.9739 \\
\hline \multirow[t]{6}{*}{ Specialised banks } & 2003 & 1.0000 & 1.0000 & 0.9648 & 0.8087 & 0.7565 & 0.7511 \\
\hline & 2004 & 0.9263 & 0.9194 & 0.9078 & 0.9310 & 0.9093 & 0.9044 \\
\hline & 2005 & 0.9548 & 0.8851 & 0.9211 & 0.9572 & 0.9992 & 0.9451 \\
\hline & 2006 & 0.9911 & 0.8351 & 0.9105 & 1.0000 & 1.0000 & 0.9594 \\
\hline & 2007 & 0.9846 & 0.7420 & 0.8844 & 0.9607 & 0.9926 & 0.9945 \\
\hline & 2008 & 1.0000 & 0.8386 & 0.9030 & 0.9743 & 0.9992 & 0.9970 \\
\hline \multirow[t]{6}{*}{ Private banks } & 2003 & 0.7949 & 0.9876 & 0.9502 & 1.0000 & 0.9740 & 0.8592 \\
\hline & 2004 & 0.9364 & 0.9383 & 0.9681 & 1.0000 & 0.9682 & 1.0000 \\
\hline & 2005 & 1.0000 & 0.9333 & 1.0000 & 1.0000 & 0.9877 & 0.9572 \\
\hline & 2006 & 0.9897 & 0.9527 & 0.9831 & 0.9752 & 0.9671 & 0.9750 \\
\hline & 2007 & 0.8971 & 0.9336 & 0.9016 & 1.0000 & 0.9816 & 1.0000 \\
\hline & 2008 & 0.8806 & 0.8684 & 0.9122 & 1.0000 & 0.9487 & 1.0000 \\
\hline \multirow[t]{6}{*}{ Total } & 2003 & 0.8951 & 0.9777 & 0.9510 & 0.9328 & 0.9033 & 0.8483 \\
\hline & 2004 & 0.9482 & 0.9438 & 0.9552 & 0.9770 & 0.9510 & 0.9444 \\
\hline & 2005 & 0.9789 & 0.9319 & 0.9671 & 0.9820 & 0.9907 & 0.9537 \\
\hline & 2006 & 0.9912 & 0.9091 & 0.9528 & 0.9884 & 0.9871 & 0.9740 \\
\hline & 2007 & 0.9589 & 0.7707 & 0.9130 & 0.9780 & 0.9871 & 0.9944 \\
\hline & 2008 & 0.9385 & 0.8625 & 0.9260 & 0.9867 & 0.9765 & 0.9903 \\
\hline
\end{tabular}

Table 2 provides a summary of estimated pure, scale and mix efficiency levels of aggregate groupings of individual banks during the period 2003-2008. The results reveal that under the intermediation approach, the average pure technical efficiency (OTE) of the public banks is relatively higher in the post-regulation era (2006-2008). However, the OTE for private banks shows a large decline over the same period. These changes coincided with major banking reforms initiated in 2005. Due to these government initiatives, public banks were obliged to provide more direct credit facilities, grant lower profit rates and subsidized-banking services to several less-privileged areas. It may be argued that due to this large expansion in public banks' advances to the less-developed regions, public banks became more purely efficient than private banks in terms of the provision of loans. On the other hand, the significantly lower pure 
efficiency of private banks after 2005 can also be attributed to their poor management of deposits. Put otherwise, because the profit rates given to deposits by private banks were higher than those of public banks, they attracted large deposits, but they initially could not utilize them efficiently in investment projects (CBI 2007a). ${ }^{7}$

In contrast, Table 2 also reveals that under the intermediation approach, public banks on average became highly scale and mix inefficient after the 2005 reforms. In general, average scale efficiency estimates of the commercial and specialised banks were quite low, varying below 94 percent and 84 percent respectively, in the post-regulation era. These suboptimal levels of scale efficiency and mix efficiency can be attributed to the lack of independence public banks have from the government in relation to management of their inputs-outputs.

Under the operating approach, our technical and mix efficiency results are unambiguously in contrast to those of Arjomandi et al (2012), thus highlighting the need to analyse performance and efficiency from multiple perspectives. Our operating efficiency estimates in Table 2 reveal that private banks were fully technically efficient every year during the sample period, with the only exception being 2006. The results also indicate that private banks were generally the most efficient banks in terms of the allocation of inputs and outputs (mix efficiency). At least two reasons are behind the relatively poor performance of the public banks: 1) public banks focus more on creating employment opportunities in rural areas and among people with low skills; and 2) by providing artificially low profit rates, public banks are also obliged to follow the government policy objectives of advancing a relatively large quantity of loans to regions considered as high priorities.

\footnotetext{
7 The ratio of private banks' deposits on total deposits in the banking system increased considerably from 7 percent in 2004 to 23.8 percent in 2008 .
} 
Table 3

Total factor productivity change and its components (2003-2008) ${ }^{\text {a b }}$

\begin{tabular}{|c|c|c|c|c|c|c|c|}
\hline \multirow{2}{*}{ Financial Institutions } & \multirow{2}{*}{ Year } & \multicolumn{6}{|c|}{ Intermediation approach } \\
\hline & & $\Delta \mathrm{TFP}$ & $\Delta$ Tech & $\Delta$ Eff & $\triangle \mathrm{OTE}$ & $\triangle \mathrm{ROSE}$ & $\triangle \mathrm{OME}$ \\
\hline \multirow[t]{5}{*}{ Commercial banks } & 2003-2004 & 0.7656 & 0.8252 & 0.9209 & 1.1259 & 0.7734 & 1.0576 \\
\hline & 2004-2005 & 1.0206 & 1.4253 & 0.7133 & 0.9999 & 0.7201 & 0.9908 \\
\hline & 2005-2006 & 1.1901 & 1.0605 & 1.1234 & 1.0130 & 1.1266 & 0.9843 \\
\hline & 2006-2007 & 1.1417 & 2.2734 & 0.5039 & 1.0023 & 0.5093 & 0.9870 \\
\hline & 2007-2008 & 0.8179 & 0.8432 & 0.9765 & 0.9387 & 1.0254 & 1.0146 \\
\hline \multirow[t]{5}{*}{ Specialised banks } & 2003-2004 & 0.8762 & 0.8252 & 1.0597 & 0.9263 & 1.2225 & 0.9358 \\
\hline & 2004-2005 & 1.1186 & 1.4253 & 0.7820 & 1.0404 & 0.7362 & 1.0209 \\
\hline & 2005-2006 & 0.9110 & 1.0605 & 0.8553 & 1.0443 & 0.8319 & 0.9846 \\
\hline & 2006-2007 & 1.8700 & 2.2734 & 0.8104 & 0.9934 & 0.8464 & 0.9638 \\
\hline & 2007-2008 & 0.9682 & 0.8432 & 1.1448 & 1.0162 & 1.0971 & 1.0269 \\
\hline \multirow[t]{5}{*}{ Private banks } & 2003-2004 & 0.9065 & 0.8252 & 1.1298 & 1.2447 & 0.8877 & 1.0226 \\
\hline & 2004-2005 & 1.0733 & 1.4253 & 0.7830 & 1.0854 & 0.6959 & 1.0366 \\
\hline & 2005-2006 & 1.1838 & 1.0605 & 1.1107 & 0.9897 & 1.1417 & 0.9831 \\
\hline & 2006-2007 & 0.9530 & 2.2734 & 0.4290 & 0.9078 & 0.5147 & 0.9182 \\
\hline & 2007-2008 & 0.9633 & 0.8432 & 1.1437 & 0.9720 & 1.1582 & 1.0159 \\
\hline \multirow[t]{5}{*}{ Total } & 2003-2004 & 0.8494 & 0.8252 & 1.0619 & 1.0989 & 0.9612 & 1.0053 \\
\hline & 2004-2005 & 1.0708 & 1.4253 & 0.7595 & 1.0419 & 0.7174 & 1.0161 \\
\hline & 2005-2006 & 1.0950 & 1.0605 & 1.0327 & 1.0157 & 1.0334 & 0.9840 \\
\hline & 2006-2007 & 1.3215 & 2.2734 & 0.5771 & 0.9678 & 0.6235 & 0.9563 \\
\hline & 2007-2008 & 0.9164 & 0.8432 & 1.0873 & 0.9756 & 1.0935 & 1.0191 \\
\hline \multirow{2}{*}{ Financial Institutions } & \multirow[b]{2}{*}{ Year } & \multicolumn{6}{|c|}{ Operating approach } \\
\hline & & $\Delta \mathrm{TFP}$ & $\Delta$ Tech & $\Delta \mathrm{Eff}$ & $\Delta \mathrm{OTE}$ & $\Delta$ ROSE & $\triangle \mathrm{OME}$ \\
\hline \multirow[t]{5}{*}{ Commercial banks } & 2003-2004 & 0.8291 & 0.6976 & 1.1885 & 1.0108 & 1.1758 & 1.0157 \\
\hline & 2004-2005 & 1.0265 & 1.0097 & 1.0167 & 0.9887 & 0.9963 & 1.0336 \\
\hline & 2005-2006 & 1.0311 & 1.0341 & 0.9971 & 1.0013 & 0.9654 & 1.0383 \\
\hline & 2006-2007 & 1.0448 & 0.9995 & 1.0453 & 0.9832 & 1.0613 & 1.0013 \\
\hline & 2007-2008 & 0.9874 & 0.9888 & 0.9986 & 1.0139 & 1.0002 & 0.9859 \\
\hline \multirow[t]{5}{*}{ Specialised banks } & 2003-2004 & 1.1908 & 0.6976 & 1.7071 & 1.5203 & 1.0056 & 1.2140 \\
\hline & 2004-2005 & 1.2389 & 1.0097 & 1.2270 & 1.0363 & 1.1355 & 1.0653 \\
\hline & 2005-2006 & 0.9750 & 1.0341 & 0.9429 & 1.0516 & 0.8798 & 1.0264 \\
\hline & 2006-2007 & 1.0459 & 0.9995 & 1.0464 & 0.9607 & 1.0519 & 1.0388 \\
\hline & 2007-2008 & 0.7907 & 0.9888 & 0.7996 & 1.0162 & 0.7822 & 1.0025 \\
\hline \multirow[t]{5}{*}{ Private banks } & 2003-2004 & 0.9373 & 0.6976 & 1.3435 & 1.0000 & 1.1357 & 1.1979 \\
\hline & 2004-2005 & 1.0262 & 1.0097 & 1.0163 & 1.0000 & 1.0598 & 0.9572 \\
\hline & 2005-2006 & 1.0661 & 1.0341 & 1.0309 & 0.9752 & 1.0342 & 1.0191 \\
\hline & 2006-2007 & 1.6033 & 0.9995 & 1.6041 & 1.0275 & 1.5254 & 1.0278 \\
\hline & 2007-2008 & 0.8619 & 0.9888 & 0.8717 & 1.0000 & 0.8717 & 1.0000 \\
\hline \multirow[t]{5}{*}{ Total } & 2003-2004 & 0.9857 & 0.6976 & 1.4130 & 1.1770 & 1.1057 & 1.1426 \\
\hline & 2004-2005 & 1.0972 & 1.0097 & 1.0867 & 1.0083 & 1.0639 & 1.0187 \\
\hline & 2005-2006 & 1.0241 & 1.0341 & 0.9903 & 1.0094 & 0.9598 & 1.0279 \\
\hline & 2006-2007 & 1.2313 & 0.9995 & 1.2319 & 0.9905 & 1.2129 & 1.0226 \\
\hline & 2007-2008 & 0.8800 & 0.9888 & 0.8900 & 1.0100 & 0.8847 & 0.9961 \\
\hline
\end{tabular}

${ }^{\mathrm{a}} \triangle T F P=\Delta T e c h \times \triangle E f f$ and $\triangle E f f=\triangle O T E \times \triangle R O S E \times \triangle O M E$.

${ }^{\mathrm{b}}$ Results for individual banks are available from the authors upon request. 
Table 3 shows the decomposition to changes in total factor productivity $(T F P)$ and its components, technical changes $\Delta(T e c h)$ and efficiency changes $\Delta(E f f)$. In addition, we also report the three components of the efficiency changes: 1) changes in output-oriented pure technical efficiency (QOTE); 2) the residual scale efficiency ( $\triangle \mathrm{ROSE}$ ); and 3) mix efficiency $(\triangle \mathrm{OME})$. Estimated values that are greater than unity indicate an improvement in the corresponding measures, with values less than unity indicating the opposite. Consistent with our theoretical expectations, results show that technical changes $(\Delta T$ Tech) are the same for each bank (and bank grouping) in each year. Thus, $\Delta$ Tech only captures the effect of technological changes as well as the effects of government regulations and central bank policies.

In general, Table 3 shows that the banking industry experienced improvements in terms of $\Delta \mathrm{TFP}$ in period 2004-2007 under both approaches. The extensive decline of $\Delta \mathrm{TFP}$ in 2007-2008 was quite noticeable, because it was due to negative TFP changes of all groups experienced, especially under the operating approach. A general comparison of various indexes presented in Table 3 reveals that under the intermediation approach the main contributor of $\Delta$ TFP in the industry were $\triangle$ ROSE as well as technical changes 4 Tech). Under the operating approach, changes in scale efficiency ( $\mathrm{ROSE}$ ) solely constituted the significant component of changes in total factor productivity changes $(\Delta \mathrm{TFP})$. These findings further support that scale inefficiency is a significant reason behind TFP shortfalls in the industry. For instance, in 2006-2007 under the intermediation approach, commercial banks, specialised banks and private banks experienced an extensive technology advance of 127 percent $(\Delta$ Tech $=2.27)$, however, a considerable deterioration of scale efficiency negated the significant positive changes in $\Delta$ Tech and thus limited the extent of TFP growth over this period. Hence, TFP changes for commercial banks, specialised banks and private banks showed net changes of 14 percent (commercial banks), 87 percent (specialised banks) and -5 percent (private banks). This result, under the intermediation approach, may not necessarily be undesirable for private banks, because private banks do not 
have to allocate and manage their funds according to government priorities. Besides, under the operating approach, private banks showed a 60 percent positive change in TFP in the same period.

By looking at the upper section of Table 3 in 2004-2005, 2005-2006 and 2006-2007, the industry's estimates of $\Delta$ Tech were greater than unity, suggesting that an overall technological progress in the industry is apparent. However, from a profit-oriented perspective (the lower part of Table 3) the estimates of $\Delta$ Tech were relatively smaller in 2004-2005 and 2005-2006, and even negative in 2006-2007. One possible explanation for these changes is based on the technological advances in the banking industry which commenced in 2004, such as the ubiquitous use of automated teller machines (ATM), credit cards, debit cards and onlinebranches, as well as the increased pressure on commercial banks to expand credit facilities in 2006. One may argue that these changes led to an expansion of the intermediation services and operating costs simultaneously. In 2007-2008, the industry experienced a large fall in technical change ( $\Delta$ Tech) under both approaches, and this was probably due to a substantial rise in the public banks’ NPLs.

\section{Conclusions}

In the present study we analysed both intermediation and operational performance of Iranian banks by means of a DEA-based decomposition of the Hicks-Moorsteen TFP index. We estimated various efficiency measures and components of productivity changes of the banking industry over the period 2003-2008 using the operating (profit-oriented) approach, and compared our findings with those of Arjomandi et al. (2012), which were based solely on the intermediation approach.

Firstly, comparing public and private banks, it is shown that public banks' pure technical efficiency tended to be higher than that of private banks after the imposition of regulatory 
reforms in 2005 using the intermediation approach. This is likely because: 1) public banks were mandated by government regulations to increase loans to various groups, defined in this approach as output, and were therefore more likely to be measured as relatively efficient; 2) private banks, could not manage their inputs (deposits) efficiently which increased markedly due to the profit rate differentials between public and private banks. However, under the profitoriented operating approach, private banks were found to be relatively highly technically and mix efficient during the entire sample period. This is a major contribution to the literature from this paper as it highlights the need to analyse banks from both a service and revenue performance perspective. Private banks in Iran can independently pursue revenue maximization in their allocation of resources. However, it appears that the achievement of regulatory goals for public banks to increase lending, which increased their efficiency under the intermediation approach, was to the detriment of their performance under this revenue based approach.

We did not find any individual bank as the best performer using both approaches and estimates of efficiency, again suggesting that it is difficult to achieve efficiency in the provision of services and also be relatively profitable within the new regulatory framework. In general, our findings indicate that, irrespective of which approach is considered, the industry experienced some improvements of TFP in 2004-2007 and a significant TFP deterioration in 2007-2008. Scale inefficiency is one of the most pressing reasons for the industry's overall inefficiency during the post-regulation period (under both approaches). We may attribute this to the lack of financial institution independence and the regulatory interventions that adversely affected the way inputs and outputs were managed in the banking system. However, since the market is noncompetitive and the public banks must follow government policies, the poor scale efficiency results may not be solely interpreted as inefficiency and performance mismanagement of individual public banks. Under current regulatory circumstances, they have no choice other than implementing the normative policies imposed by the government and the Central Bank in the 
interests of equity and fairness. If revenue maximizing was to be of paramount importance, we may conclude that the independence of the central bank and limited government regulatory power in the banking industry could boost the efficiency and productivity of the banking system. 


\section{References}

Aly, H.Y., Grabowski, R., Pasurka, C., Rangan, N., 1990. Technical, scale, and allocative efficiencies in U.S. banking: An empirical investigation. The Review of Economics and Statistics 72, 211-218.

Arjomandi, A., Harvie, C., Valadkhani, A., 2012. An empirical analysis of Iran’s banking performance. Studies in Economics and Finance 24(4), 287-300.

Arora, H., Arora, P., 2012. Bank productivity measurement using Hicks-Moorsteen indices: Evidence from Indian public sector banks. International Journal of Business Performance Management 13(3), 386-407.

Arora, H., Arora, P., 2013. Measuring and decomposing productivity change using HicksMoorsteen index numbers: Evidence from Indian banks. International Journal of Productivity and Quality Management 11(1), 73-95.

Avkiran, N.K., 1999. The evidence on efficiency gains: The role of mergers and the benefits to the public. Journal of Banking and Finance 23, 991-1013.

Babalos, V., Caporale, G.M., Philippas, N., 2012. Efficiency evaluation of Greek equity funds. Research in International Business and Finance 26, 317-333.

Bauer, P.W., Berger, A.N., Ferrier, G.D., Humphrey, D. B., 1998. Consistency conditions for regulatory analysis of financial institutions: A comparison of frontier efficiency methods. Journal of Economics and Business 50, 85-114.

Berg, S. A., Forsund, F. R., Jansen, E. S., 1992. Malmquist indices of productivity growth during the deregulation of Norwegian banking 1980-1989. Scandinavian Journal of Economics 94, 211-228.

Berger, A.N., Hanweck, G.A., Humphrey, D.B., 1987. Competitive viability in banking: Scale, scope, and product mix economies. Journal of Monetary Economics 20, 501-520.

Berger, A.N., Mester, L.J., 2003. Explaining the dramatic changes in performance of US banks: Technological change, deregulation, and dynamic changes in competition. Journal of Financial Intermediation 12, 57-95.

Bjurek, H., 1996. The Malmquist total factor productivity index. Scandinavian Journal of Economics 98(2), 303-313.

Burgess, J.F., Wilson, P.W., 1995. Decomposing hospital productivity changes, 1985-1988: A nonparametric Malmquist approach. Journal of Productivity Analysis 6, 343-363.

Casu, B., Girardone, C., 2004. Financial conglomeration: Efficiency, productivity and strategic drive. Applied Financial Economics 14, 687-696.

Casu, B., Girardone, C., Molyneux, P., 2004. Productivity change in European banking: A comparison of parametric and non-parametric approaches. Journal of Banking and Finance 28, 2521-2540. 
Caves, D. W., Christensen, L. R., Diewert, W. E., 1982. The economic theory of index numbers and the measurement of input, output, and productivity. Econometrica 50, 1393-1414.

CBI, 2005. Iranian Banks Performance Report 2005. Central Bank of Iran, Tehran.

CBI, 2007a. Annual Report 2007. Central Bank of Iran, Tehran.

CBI, 2007b. Iranian Banks Performance Report 2007. Central Bank of Iran, Tehran.

CBI, 2008. Iranian Banks Performance Report 2008. Central Bank of Iran, Tehran.

Chen, Y., Lin, C., 2007. Empirical study on the efficiency analysis of Australian banks. Banks and Bank Systems 2(4), 38-49.

Chung, Y., Färe, R., Grosskopf, S., 1997. Productivity and undesirable outputs: A directional distance function approach. Journal of Environmental Management 51, 229-240.

Clark, J. A., 1996. Economic cost, scale efficiency, and competitive viability in banking. Journal of Money, Credit, and Banking 28, 342-64.

Coelli, T. J., Rao, D. S. P., 2005. Total factor productivity growth in agriculture: A Malmquist index analysis of 93 countries, 1980-2000. Agricultural Economics 32, 115-134.

Dadgar, Y., Nemat, Z., 2007. Applying DEA in analysing Iranian economy. Journal of Hawza and University Studies 4(7), 11-54.

Diewert, W. E., 1992. Fisher ideal output, input, and productivity indexes revisited. Journal of Productivity Analysis 3, 211-248.

Drake, L., Hall, M. J. B., Simper, R., 2006. The impact of macroeconomic and regulatory factors on bank efficiency: A non-parametric analysis of Hong Kong's banking system. Journal of Banking and Finance 30, 1443-1466.

Epure, M., Kerstens, K., Diego, D., 2011. Technology-based total factor productivity and benchmarking: New proposals and an application. Omega International Journal of Management Science 39(6), 608-619.

Färe, R., Grosskopf, S., Lindgren, B., Roos, P., 1992. Productivity changes in Swedish pharmacies 1980-1989: A nonparametric Malmquist approach. Journal of Productivity Analysis 3, 85-101.

Färe, R., Grosskopf, S., Norris, M., Zhang, Z., 1994. Productivity growth, technical progress, and efficiency change in industrialized countries. American Economic Review 84, 66-83.

Farrell, M. J., 1957. The measurement of productive efficiency. Journal of the Royal Statistical Society 120, 253-281.

Fethi, M. D., Pasiouras, F., 2010. Assessing bank performance with operational research and artificial intelligence techniques: A survey. European Journal of Operational Research 204, 189198. 
Figueira, C., Nellis, J., Parker, D., 2009. Banking performance and technological change in noncore EU countries: A study of Spain and Portugal. Studies in Economics and Finance 26(3), $155-170$.

Gilbert, R. A., Wilson, P. W., 1998. Effect of deregulation in the productivity of Korean banks. Journal of Economics and Business 50(2), 133-155.

Gitto S., Mancuso P., 2012. Bootstrapping the Malmquist indexes for Italian airports. International Journal of Production Economics 135, 403-411.

Grifell-Tatje, E., Lovell, C. A. K., 1995. A note on the Malmquist productivity index. Economics Letters 47, 169-175.

Grifell-Tatje, E. G., Lovell, C. A. K., 1997. The sources of productivity change in Spanish banking. European Journal of Operations Research 98, 364-380.

Hadian, E., Hosseini, A. A., 2004. Measuring the efficiency of the Iranian banking system using DEA approach. Quarterly Iranian Economic Researches 20, 1-25.

Hakimabady, M. T. G., Esnaasharie, A., Ahmadpour, H., 2006. A study of commercial banks' efficiency based on data envelopment analysis: Case of Bank Saderat in Mazandaran province of Iran. Bi-Quarterly Journal of Economic Essays 3(5), 127-156.

Hancock, D., 1991. A Theory of Production for the Financial Firm. Kluwer Academic Publishers, Boston.

Hasanzadeh, A., 2007. Efficiency and its determinants in the Iranian banking system. BiQuarterly Journal of Economic Essays 4(7), 75-98.

Hicks, J. R., 1961. Measurement of Capital in Relation to the Measurement of Other Economic Aggregates. In: Lutz, F.A., Hague, D.C. (Eds.), Theory of Capital. Macmillan, London.

Hoang, V. N., 2011. Measuring and decomposing changes in agricultural productivity, nitrogen use efficiency and cumulative exergy efficiency: Application to OECD agriculture. Ecological Modelling 222, 164-175.

Iturralde, M.J., Quirós, C., 2008. Analysis of efficiency of the European postal sector. International Journal of Production Economics 114, 84-90.

Kenjegalieva, K. A., Simper, R., 2011. A productivity analysis of Central and Eastern European banking taking into account risk decomposition and environmental variables. Research in International Business and Finance 25(1), 26-38.

Kerstens, K., Moulaye Hachem, B. A., De Woestyne, I. V., 2010. Malmquist and HicksMoorsteen Productivity Indices: An empirical comparison focusing on infeasibilities. Hub Research Paper 2010/3, Hogeschool Universiteit Brussel, Brussel, Belgium.

Leightner, J.E., Lovell, C.A.K., 1998. The impact of financial liberalization on the performance of Thai banks. Journal of Economics and Business 50, 115-131. 
Ma, J., Evans, D.G., Fuller, R.J., Stewart, D.F., 2002. Technical efficiency and productivity change of China's iron and steel industry. International Journal of Production Economics 76, 293-312.

Maghyereh, A. I., Awartani, B., 2012. Financial integration of GCC banking markets: A nonparametric bootstrap DEA estimation approach. Research in International Business and Finance 26(2), 181-195.

McAllister, P. H., McManus, D., 1993. Resolving the scale efficiency puzzle in banking. Journal of Banking and Finance 17, 389-405.

Mitchell, K., Onvural, N. M., 1996. Economies of scale and scope at large commercial banks: Evidence from the Fourier flexible functional form. Journal of Money, Credit, and Banking 28, 178-99.

Moorsteen, R. H., 1961. On measuring productive potential and relative efficiency. Quarterly Journal of Economics 75, 151-167.

Mukherjee, K., Ray S. C., Miller, S. M., 2001. Productivity growth in large US commercial banks: The initial post-deregulation experience. Journal of Banking and Finance 25, 913-939.

Neal, P., 2004. X-efficiency and productivity change in Australian banking. Australian Economic Papers 43, 174-191.

O’Donnell, C. J., 2010a. Measuring and decomposing agricultural productivity and profitability change. Australian Journal of Agricultural and Resource Economics 54, 527-560.

O’Donnell, C. J., 2010b. DPIN version 1.0: A program for decomposing productivity index numbers. Working Paper. Centre for Efficiency and Productivity Analysis, University of Queensland.

O’Donnell, C. J., 2012a. An aggregate quantity framework for measuring and decomposing productivity change. Journal of Productivity Analysis 38(3), 255-272.

O’Donnell, C. J., 2012b. Nonparametric estimates of the components of productivity and profitability change in U.S. agriculture. American Journal of Agricultural Economics 94, 873890.

Pasiouras, F., 2008. Estimating the technical and scale efficiency of Greek commercial banks: The impact of credit risk, off-balance sheet activities, and international operations. Research in International Business and Finance 22(3), 301-318.

Ray, S. C., Desli, E., 1997. Productivity growth, technical progress, and efficiency change in industrialized countries: Comment. American Economic Review 87, 1033-1039.

Sathye, M., 2001. X-efficiency in Australian banking: An empirical investigation. Journal of Banking and Finance 25, 613-630.

Sathye, M., 2002. Measuring productivity changes in Australian banking: An application of Malmquist indices. Managerial Finance 28, 48-59. 
Sealey, C. W., Lindley, J., 1977. Inputs, outputs and a theory of production and cost at depository financial institutions. Journal of Finance 32, 1252-1266.

Simões, P., Marques, R. C, 2012. Influence of regulation on the productivity of waste utilities: What can we learn with the Portuguese experience? Waste Management 32(6), 1266-1275.

Sturm, J., Williams, B., 2004. Foreign bank entry, deregulation and bank efficiency: Lessons from the Australian experience. Journal of Banking and Finance 28, 1775-1799.

Sufian, F., 2006. Post crisis productivity and efficiency of commercial banks: Empirical evidence from Malaysia. International Journal of Economic Research 3(2), 143-163.

Sufian, F., 2007. Determinants of bank efficiency during unstable macroeconomic environment: Empirical evidence from Malaysia. Research in International Business and Finance 23(1), 5477.

Sufian, F., 2008. Revenue shifts and non-bank financial institutions' productivity: Empirical evidence from Malaysia. Studies in Economics and Finance 25(2), 76-92.

Valadkhani, A., 2004. What determine private investment in Iran? International Journal of Social Economics 31(5/6), 457-468.

Wheelock, D.C., Wilson, P.W., 1997. New evidence on returns to scale and product mix among U.S. commercial banks. Working Paper. Department of Economics, University of Texas at Austin.

Wheelock, D. C., Wilson, P. W., 1999. Technical progress, inefficiency and productivity change in U.S banking 1984-1993. Journal of Money, Credit and Banking 31, 212-234.

Worthington, A., 1999. Malmquist indices of productivity change in Australian financial services. Journal of International Financial Markets, Institutions and Money 9(3), 303-320. 